\title{
Gambaran Kepuasan Pasien Rawat Jalan terhadap Pelayanan di Rumah Sakit Islam Jakarta Sukapura (RSIJS) Tahun 2015
}

\author{
Chairunnisa $^{1}$ Maya Puspita ${ }^{2}$ \\ ${ }^{1,2}$ Program Studi Kesehatan Masyarakat Fakultas Kedokteran dan Kesehatan Universitas Muhammadiyah \\ Jakarta
}

\begin{abstract}
Abstrak
Berdasarkan data yang diperoleh dari bagian humas RSIJS mengenai kritik dan saran menunjukan adanya keluhan terhadap pelayanan. Tujuan penelitian ini untuk mengetahui gambaran tingkat kepuasan pasien terhadap pelayanan di RSIJS. Penelitian ini merupakan penelitian survei deskriptif melalui pendekatan kuantitatif, penelitian dilakukan pada bulan Agustus 2015. Jumlah responden sebanyak 110 responden. Teknik pengambilan sampel adalah Acidental sampling Alat analisis yang digunakan adalah Importance-Performance Analysis (IPA). Hasil uji IPA dalam diagram kartesius menunjukan atribut yang masuk dalam kuadran A adalah kebersihan kamar mandi, kebersihan poli rawat jalan, keramahan dan kesantunan petugas pendaftaran dan kasir, ketepatan waktu dokter dalam memulai memberikan pelayanan dan kedisiplinan waktu pelayanan. Atribut yang masuk dalam kuadran B adalah prosedur penerimaan pasien dilayani secara cepat dan tidak berbelit-belit, kecepatan bagian pendaftaran dan kasir dalam pelayanan, ketepatan waktu perawat dalam memberikan pelayanan, cepat tanggap dokter, perawat, petugas pendaftaran dan kasir dalam membantu pasien, perawat memperhatikan sungguh-sungguh kepada pasien, pemberian pelayanan terhadap pasien tanpa pilih-pilih. Atribut yang masuk dalam kuadran $\mathrm{C}$ adalah terciptanya suasana kekeluargaan antara perawat dengan pasien, dan, adanya media elektronik tv di ruang tunggu. Atribut yang masuk dalam kuadran $\mathrm{D}$ adalah kebersihan dan kenyamanan ruang tunggu, terciptanya suasana kekeluargaan antara dokter dan pasien, dokter memberikan kesempatan bertanya kepada pasien dan waktu pelayanan yang cukup. adanya kotak saran untuk kritik dan keluhan, tenaga medis dan karyawan rumah sakit berpenampilan rapi dan bersih. Saran yang dapat diberikan antara lain : meningkatkan evaluasi kinerja pegawai melalui peningkatan kedisiplinan dan lebih diperhatikan untuk kebersihan kamar mandi dan kebersihan poli rawat jalan dan meningkatkan keramahan petugas.
\end{abstract}

Kata Kunci: Kepuasan pasien, rawat jalan, pelayanan

\section{Overview Outpatient Satisfaction of Services at Jakarta Sukapura Hospital Islam In 2015}

\begin{abstract}
Based on data obtained from the publicity department of RSIJS about criticism and suggestions showed complaints against the service. This research purpose to describe the level of patient satisfaction for service in RSIJS. This research is a descriptive survey through a quantitative approach, the research was conducted in August 2015. The number of respondents were 110 respondents. The sampling technique is Acidental sampling analysis equipment is ImportancePerformance Analysis (IPA). IPA test results in a Cartesian diagram shows the attributes included in quadrant $\mathrm{A}$ is the cleanliness of the bathroom, cleanliness poly outpatient care, hospitality and politeness registration clerk and cashier, timeliness physicians in providing care and discipline start time of service. Attributes included in quadrant B is the procedure of admission of patients served quickly and uncomplicated, speed part of registration and cashier in service, timeliness of nurses in providing services, responsive physicians, nurses, registration clerk and cashier in helping the patient, the nurse noticed earnestly to the patient, the delivery of services to patients without discrimination. Attributes included in quadrant $\mathrm{C}$ is the creation of a family atmosphere between nurses and patients, and, the electronic media tv in the lounge. Attributes included in quadrant D is
\end{abstract}


the cleanliness and comfort of the lounge area, creating a family atmosphere between the doctor and the patient, the doctor gives the patient the opportunity to ask and sufficient service time. the suggestion box for criticism and complaints, medical personnel and hospital employees look neat and clean. Advice can be given include: improving the evaluation of employee performance through increased discipline and more attention to the cleanliness of the bathroom and cleanliness poly outpatient and improve hospitality workers.

Keywords: Patient satisfaction, outpatient, service

Korespondensi: Chairunnisa, Program Studi Kesehatan Masyrakat Fakultas Kedokteran dan Kesehatan Universitas Muhammadiyah Jakarta, JL KH Ahmad Dahlan Cirendeu Ciputat Tangerang Selatan 15419, mobile: 08161161884, email: nisa_cna@gmail.com 


\section{Pendahuluan}

Perkembangan dan peningkatan jasa pelayanan rumah sakit dari tahun ketahun semakin menjadi perhatian masyarakat. Hal ini, dapat dilihat dari Peningkatan jumlah Rumah Sakit. Berdasarkan data hasil laporan Riset fasilitas kesehatan (Rifaskes) 2011 peningkatan jumlah Rumah Sakit Umum (RSU) dan Rumah Sakit Khusus (RSK) serta Tempat Tidurnya (TT). Pada tahun 2009 terdapat 1.202 RSU dengan kapasitas 141.603 TT, yang kemudian meningkat menjadi 1.725 RSU dengan 245.340 TT pada tahun 2013. Pada tahun 2013, sebagian besar (53\%) RSU adalah milik swasta (profit dan non profit), disusul $(30,4 \%)$ RSU milik pemerintah Kabupaten/ Kota. RSK juga berkembang pesat, yakni dari $321 \mathrm{RSK}$ dengan 22.877 TT pada tahun 2009 menjadi 503 RSK dengan 33.110 TT pada tahun 2013. Pada tahun 2013, lebih dari separuh $(51,3 \%)$ RSK itu adalah RS Bersalin dan RS Ibu dan Anak. Data oktober 2014 menunjukkan bahwa saat ini terdapat 2.368 RS dan diprediksikan jumlah RS akan menjadi 2.809 pada tahun 2017, dengan laju pertumbuhan jumlah RS rata-rata 147 per tahun. ${ }^{1}$ Dengan demikian semakin meningkatnya jumlah rumah sakit maka persaingan kualitas pelayanan, harga, promosi diantara sekian banyaknya rumah sakit. Dalam kondisi persaingan tersebut, hal utama yang harus diprioritaskan adalah mengenai kepuasan pelanggan atau pasien agar dapat bertahan. Untuk mengetahui hal-hal apa saja yang dianggap penting oleh pasien dan berusaha untuk menghasilkan kinerja (performance) sebaik mungkin sehingga dapat memuaskan pelanggan, maka perlu dilakukan “importance and performance analysis. ${ }^{2}$

Sebagai pelayanan kesehatan masyarakat umum, Rumah sakit memiliki masalah utama yaitu mengenai pelayanan yang diberikan apakah sudah sesuai harapan pasien atau tidak. Oleh karena itu, pihak Rumah Sakit dituntut untuk selalu menjaga kepercayaan pasien dengan meningkatkan mutu pelayanannya. ${ }^{3}$ Rumah sakit sebagai salah satu penyelenggara kesehatan dalam pelaksanaannya dituntut untuk menyediakan pelayanan yang bermutu seperti dalam UU RI No 36 Tahun 2009 Bab 4 Pasal 54 menyebutkan bahwa penyelenggaraan pelayanan kesehatan dilaksanakan secara bertanggung jawab, aman, bermutu, serta merata dan nondiskriminatif. Menurut Azwar, pelayanan kesehatan yang bermutu adalah pelayanan kesehatan yang dapat memuaskan setiap pemakai jasa pelayanan kesehatan sesuai dengan tingkat kepuasan rata-rata penduduk serta yang penyelenggaraannya sesuai dengan standar dan kode etik profesi yang telah ditetapkan. ${ }^{4}$

Pasien mengartikan pelayanan yang bermutu dan efektif adalah jika pelayanannya nyaman, menyenangkan, dan petugasnya ramah yang mana secara keseluruhan memberikan kesan kepuasan terhadap pasien. Sedangkan dari pihak pemberi pelayanan mengartikan pelayanan yang bermutu dan 
efisien jika pelayanannya sesuai dengan standar pemerintah. Adapun kondisi yang sering dikeluhkan oleh pemakai jasa rumah sakit adalah: sikap dan tindakan dokter atau perawat, sikap petugas administrasi, sarana yang kurang memadai, lambannya pelayanan, persediaan obat, tarif pelayanan, peralatan medis dan lain-lain. ${ }^{4}$

Penelitian lain yang dilakukan oleh Smith dan Metzner (1970) dalam (Azwar 1996), untuk para dokter sebagai penyelenggara pelayanan kesehatan, dimensi mutu pelayanan kesehatan yang dipandang paling penting adalah pengetahuan ilmiah yang dimiliki oleh dokter (80\%), kemudian baru menyusul perhatian dokter secara pribadi kepada pasien (60\%), keterampilan yang dimiliki dokter (50\%), efisiensi pelayanan kesehatan (45\%) serta kenyamanan pelayanan yang dirasakan oleh pasien (8\%). Sedangkan untuk pasien sebagai pemakai jasa pelayanan kesehatan, dimensi mutu pelayanan yang dipandang paling penting adalah efisiensi pelayanan kesehatan (45\%), kemudian baru menyusul perhatian dokter secara pribadi kepada pasien (40\%), pengetahuan ilmiah yang dimiliki dokter (40\%), keterampilan yang dimiliki dokter (35\%), serta kenyamanan pelayanan yang dirasakan oleh pasien $(35 \%){ }^{4}$

Parasuraman, Zeithmal dan Berry (1990) dalam (Supranto 2011) mengidentifikasikan lima kelompok dimensi mutu yang digunakan untuk mengevaluasi kepuasan pelanggan dalam bidang jasa yaitu: bukti langsung/dapat diraba/sarana fisik (tangibles), keandalan pelayanan (reliability), ketanggapan petugas (responsiveness), jaminan/ keyakinan (assurance) dan empati (empathy).RSIJ Sukapura sebagai salah satu fasilitas kesehatan yang terdapat di wilayah Jakarta Utara tidak dapat terhindar dari pengaruh reformasi di bidang kesehatan.dengan kondisi masyarakat yang semakin kritis terhadap mutu pelayanan kesehatan menuntut rumah sakit dapat memberikan pelayanan yang bermutu. Untuk itu perlu dikembangkan upaya yang maksimal baik kekuatan internal maupun kekuatan eksternal yang ada di rumah sakit untuk memberikan pelayanan yang memuaskan kepada pasien. $^{2}$

Berdasarkan data yang diperoleh dari bagian rekam medis RSIJ Sukapura dilihat dari jumlah kunjungan pasien rawat jalan pada bulan mei sampai bulan juli pada tahun 2015 terdapat penurunan jumlah kunjungan pasien rawat jalan pada setiap bulannya. Data jumlah kunjungan pasien rawat jalan pada bulan mei sebanyak 5402 mengalami penurunan pada bulan juni dengan jumlah kunjungan sebanyak 5375 dan pada bulan juli mengalami penurunan jumlah kunjungan sebanyak 739 yaitu 4636 kunjungan. Penurunan tersebut menunjukan adanya kemungkinan ketidakpuasan pasien dengan pelayanan yang diberikan, sehingga perlu adanya pengukuran mengenai kepuasan pasien untuk mengetahui mutu pelayanan terkait dengan tingkat kepuasan pasien. 
Menurut Wijono, tingkat kepuasan adalah suatu fungsi dari perbedaan antara penampilan yang dirasakan dan harapan. Ada 3 tingkat kepuasan, yaitu: bila penampilan kurang dari harapan, pelanggan tidak dipuaskan. Bila penampilan sebanding dengan harapan, pelanggan puas. Bila penampilan melebihi harapan, pelanggan amat puas atau senang. ${ }^{5}$ Manajemen RSIJ Sukapura juga berusaha untuk mendapatkan informasi sebanyak-banyaknya baik dari pasien maupun keluarga pasien tentang keluhan, kritik dan saran yang didapat melalui kotak saran yang disediakan pihak RSIJ Sukapura. Berdasarkan data yang diperoleh dari bagian humas RSIJ Sukapura mengenai kritik dan saran terhadap pelayanan di RSIJ Sukapura pada bulan januari - mei 2015 menunjukkan bahwa keluhan, kritik dan saran terhadap dokter sering datang terlambat sebesar $34 \%$, perawat kurang respon terhadap pasien $37 \%$, jadwal praktek dokter masih ada tapi tidak mau melayani $33 \%$.

\section{Metode}

Penelitian ini merupakan jenis penelitian survei deskriptif melalui pendekatan kuantitatif. Penelitian dilakukan di Ruang Rawat Jalan Rumah Sakit Islam Jakarta Sukapura Jakarta Utara pada bulan Agustus 2015. Populasi dalam penelitian ini adalah semua pasien rawat jalan di RSIJ Sukapura terhitung dari 3 bulan terakhir saat penelitian yaitu dari bulan mei sampai juli tahun 2015 .
Diketahui jumlah populasi sebanyak 15.413 dengan rata - rata 5.128 orang perbulan, dengan besar sampel adalah 99 responden, kemudian ditambah $10 \%$ untuk menjaga apabila terdapat sampel yang tidak lengkap. Jadi jumlah sampel menjadi 110 responden.

\section{Hasil}

\section{Tabel 1 Karaktersitik Responden}

\begin{tabular}{|c|c|c|}
\hline Karakteristik & $\mathbf{n}$ & $\%$ \\
\hline \multicolumn{3}{|l|}{ Jenis Kelamin } \\
\hline - Laki-laki & 27 & 24,5 \\
\hline - Perempuan & 83 & 75,5 \\
\hline \multicolumn{3}{|l|}{ Umur } \\
\hline$-\quad \leq 38$ tahun & 56 & 50,9 \\
\hline$>38$ tahun & 54 & 49,1 \\
\hline \multicolumn{3}{|l|}{ Pendidikan } \\
\hline - Tidak Sekolah & 5 & 4,5 \\
\hline$-\quad \mathrm{SD} / \mathrm{MI}$ & 13 & 4,8 \\
\hline - $\quad$ SMP/MTS & 21 & 19,1 \\
\hline - $\quad$ SMA/MA/SMK & 53 & 48,2 \\
\hline - Diploma & 8 & 7,3 \\
\hline$-\quad S 1$ & 7 & 6,4 \\
\hline$-\quad$ S2 & 3 & 2,7 \\
\hline$-\quad$ S3 & 0 & 0,0 \\
\hline \multicolumn{3}{|l|}{ Pekerjaan } \\
\hline - $\quad$ PNS/TNI/POLRI & 7 & 6,4 \\
\hline - Karyawan Swasta & 19 & 17,3 \\
\hline - Wiraswasta & 13 & 11,8 \\
\hline - Buruh & 9 & 8,2 \\
\hline - $\quad$ IRT & 54 & 49,1 \\
\hline - Lainnya & 8 & 7,3 \\
\hline \multicolumn{3}{|l|}{ Status Pembayaran } \\
\hline - Bayar Sendiri & 11 & 10,0 \\
\hline - $\quad$ BPJS Tenaga Kerja & 14 & 12,7 \\
\hline - BPJS Kesehatan & 78 & 30,9 \\
\hline - $\quad$ Asuransi Lain & 7 & 6,4 \\
\hline
\end{tabular}

Berdasarkan Tabel 1, diketahui bahwa ada 83 orang $(75,5 \%)$ responden perempuan dan sebanyak 27 orang $(24,5 \%)$ responden berjenis kelamin laki-laki. 56 orang $(50,9) \%$ yang berusia kurang dari atau sama dengan 38 tahun, dan sebanyak 54 orang $(49,1 \%)$ yang berusia lebih dari 38 tahun. Tingkat 
pendidikan responden terbanyak adalah SMA/MA/SMK yaitu 53 orang $(48,2 \%)$ sedangkan untuk pendidikan Tidak sekolah, SD/MI, SMP/MTS, Diploma, S1, S2 dan S3 masing-masing berjumlah 5 orang (4,5\%), 13 orang $(4,8 \%), 21$ orang $(19,1 \%), 14$ orang $(12,7 \%), 8$ orang $(7,3 \%), 7$ orang $(6,4 \%), 3$ orang $(2,7 \%)$, dan 0 . Pekerjaan responden terbanyak adalah ibu rumah tangga yaitu 54 orang $(49,1 \%)$ sedangkan untuk PNS/TNI/POLRI, karyawan swasta, wiraswasta, buruh, ibu rumah tangga, dan lainnya berjumlah 7 orang $(6,4 \%), 19$ orang (17,3\%), 13 orang (11,8\%), 9 orang $(8,2 \%), 8$ orang $(7,3 \%)$. Status pembayaran responden terbanyak adalah dengan menggunakan BPJS kesehatan yaitu 78 orang $(70,9 \%)$ sedangkan untuk Bayar sendiri, BPJS tenaga kerja, dan Asuransi lain masing - masing berjumlah 11 orang $(10,0 \%), 14$ orang $(12,7 \%)$ dan 7 orang $(6,4 \%)$.

Pada bagian ini hasil penilaian responden terhadap tingkat kepentingan atau harapan dan tingkat pelaksanaan atau kenyataan berdasarkan lima dimensi mutu pelayanan (tangible, reliability, responsiveness, assurance dan empathy). Penilaian ini dengan menggunakan skala likert dengan bobot $1-4$ yang terdiri dari : sangat tidak penting (STP) dengan bobot 1, tidak penting (TP) dengan bobot 2 , penting $(\mathrm{P})$ dengan bobot 3, dan sangat penting (SP) dengan bobot 4 .

\section{a) Dimensi Tangible}

Dimensi tangible diwakilkan oleh lima atribut, yaitu tenaga medis dan karyawan rumah sakit berpenampilan rapi dan bersih (T1), kebersihan dan kenyamanan ruang tunggu (T2), kebersihan poli rawat jalan (T3), kebersihan kamar mandi pasien (T4), dan adanya media elektronik tv diruang tunggu (T5). Distribusi penilaian tingkat harapan dan kenyataan responden terhadap pelayanan berdasarkan dimensi tangible dapat dilihat pada Tabel 2 dibawah ini :

\section{Tabel 2 Distribusi Penilaian Tingkat Harapan Responden terhadap Pelayanan berdasarkan Dimensi Tangible}

\begin{tabular}{|c|c|c|c|c|}
\hline \multirow{2}{*}{ Atribut } & \multicolumn{3}{|c|}{ Jawaban } & \multirow{2}{*}{ Bobot } \\
\hline & ST & P $\mathbf{T P}$ & $\mathbf{P}$ & \\
\hline $\mathrm{T} 1$ & 2 & 0 & 71 & 37363 \\
\hline $\mathrm{T} 2$ & 0 & 0 & 59 & 51374 \\
\hline T3 & 0 & 0 & 65 & 45375 \\
\hline $\mathrm{T} 4$ & 0 & 0 & 59 & 51381 \\
\hline T5 & 0 & 18 & 77 & 15327 \\
\hline
\end{tabular}

Dari Tabel 2 diketahui bahwa penilaian responden mengenai tingkat kenyataan atau kepuasan terhadap pelayanan berdasarkan dimensi tangible adalah sebagian besar responden menyatakan penting terutama pada atribut adanya media elektronik tv diruang tunggu (T5) yaitu sebanyak 77 responden dengan bobot 327. 
Tabel 3 Distribusi Penilaian Tingkat Kenyataan Responden terhadap Pelayanan berdasarkan Dimensi Tangible

\begin{tabular}{|c|c|c|c|c|}
\hline \multirow[t]{2}{*}{ Atribu } & \multicolumn{3}{|c|}{ Jawaban } & \multirow[t]{2}{*}{ Bobot } \\
\hline & & TP & $\mathbf{P}$ & \\
\hline $\mathrm{T} 1$ & 1 & 0 & 8425 & 353 \\
\hline $\mathrm{T} 2$ & 2 & 10 & 7820 & 336 \\
\hline T3 & 2 & 16 & $75 \quad 17$ & 327 \\
\hline $\mathrm{T} 4$ & 3 & 54 & 458 & 278 \\
\hline T5 & 1 & 26 & 785 & 307 \\
\hline
\end{tabular}

Dari Tabel 3 diketahui bahwa penilaian responden mengenai tingkat kenyataan atau kepuasan terhadap pelayanan berdasarkan dimensi tangible adalah sebagian besar responden menyatakan puas terutama pada atribut tenaga medis dan karyawan rumah sakit berpenampilan rapi dan bersih (T1) yaitu sebanyak 84 responden dengan bobot 353 .

\section{b) Dimensi Reliability}

Dimensi reliability diwakilkan oleh 5 atribut, yaitu kedisiplinan waktu pelayanan (RL1), prosedur penerimaan pasien dilayani secara cepat dan tidak berbelit - belit (RL2), kecepatan bagian pendaftaran dan kasir dalam pelayanan (RL3), ketepatan waktu dokter dalam memulai memberikan pelayanan (RL4), dan ketepatan waktu perawatn dalam memulai memberikan pelayanan (RL5). Distribusi penilaian tingkat harapan dan kenyataan responden terhadap pelayanan berdasarkan dimensi reliability dapat dilihat pada Tabel 4 dibawah ini :
Tabel 4 Distribusi Penilaian Responden terhadap Tingkat Harapan Pelayanan berdasarkan Dimensi reliabilty

\begin{tabular}{lllll}
\hline Atribut & \multicolumn{4}{c}{ Jawaban } \\
\cline { 2 - 5 } & STPTP & P & SP \\
\hline RL1 & 0 & 1 & 54 & 55384 \\
RL2 & 0 & 0 & 50 & 60390 \\
RL3 & 0 & 0 & 57 & 53383 \\
RL4 & 0 & 0 & 55 & 55385 \\
RL5 & 0 & 0 & 53 & 57387 \\
\hline
\end{tabular}

Dari Tabel 4 diketahui bahwa penilaian responden mengenai tingkat harapan terhadap pelayanan berdasarkan dimensi reliability adalah sebagian besar responden menyatakan sangat penting terutama pada atribut prosedur penerimaan pasien dilayani secara cepat dan tidak berbelit-belit (RL2) yaitu sebanyak 60 responden dengan bobot 390 .

Tabel 5 Distribusi Penilaian Responden terhadap Tingkat Kenyataan Pelayanan berdasarkan Dimensi reliabilty

\begin{tabular}{llllll}
\hline \multirow{2}{*}{ Atribut } & \multicolumn{3}{c}{ Jawaban } & Bobot \\
\cline { 2 - 5 } & STP & TP & P & SP & \\
\hline RL1 & 2 & 19 & 71 & 18 & 325 \\
RL2 & 2 & 19 & 64 & 25 & 332 \\
RL3 & 0 & 19 & 68 & 23 & 334 \\
RL4 & 2 & 24 & 62 & 22 & 324 \\
RL5 & 0 & 11 & 74 & 25 & 344 \\
\hline
\end{tabular}

Dari Tabel 5 diketahui bahwa penilaian responden mengenai tingkat kenyataan atau kepuasan terhadap pelayanan berdasarkan dimensi reliabelity adalah sebagian besar responden menyatakan puas terutama pada atribut ketepatan waktu perawat dalam memulai memberikan pelayanan (RL5) yaitu sebanyak 74 responden dengan bobot 344. 


\section{c) Dimensi Responsiveness}

Dimensi responsiveness diwakilkan oleh 3 atribut, yaitu cepat tanggap dokter dan perawat dalam mengatasi keluhan pasien (RS1), dokter memberikan kesempatan bertanya kepada pasien (RS2), cepat tanggap petugas pendaftaran dan kasir dalam membantu pasien (RS3) Distribusi penilaian tingkat harapan dan kenyataan responden terhadap pelayanan berdasarkan dimensi assurance dapat dilihat pada Tabel 6 dibawah ini :

Tabel 6 Distribusi Penilaian Responden terhadap Tingkat Harapan Pelayanan berdasarkan Dimensi responsiveness

\begin{tabular}{lllll}
\hline Atribut & \multicolumn{3}{c}{ Jawaban } & Bobot \\
\cline { 2 - 5 } & STPTP & P & SP \\
\hline RS1 & 0 & 0 & 49 & 61391 \\
RS2 & 0 & 1 & 73 & 36364 \\
RS3 & 0 & 0 & 63 & 47377 \\
\hline
\end{tabular}

Dari tabel 6 diketahui bahwa penilaian responden mengenai tingkat harapan terhadap pelayanan berdasarkan dimensi resonsiveness adalah sebagian besar responden menyatakan penting terutama pada atribut dokter memberikan kesempatan bertanya kepada pasien yaitu sebanyak 73 responden dengan bobot 364

Tabel 7 Distribusi Penilaian Responden terhadap Tingkat Kenyataan Pelayanan berdasarkan Dimensi responsiveness

\begin{tabular}{lllll}
\hline Atribut & \multicolumn{3}{c}{ Jawaban } & Bobot \\
\cline { 2 - 5 } & STP & TP & P & SP \\
\hline RS1 & 4 & 14 & 72 & 20328 \\
RS2 & 1 & 10 & 81 & 18336 \\
RS3 & 0 & 17 & 72 & 21334 \\
\hline
\end{tabular}

Dari Tabel 7 diketahui bahwa penilaian responden mengenai tingkat kenyataan atau kepuasan terhadap pelayanan berdasarkan dimensi responsiveness adalah sebagian besar responden menyatakan puas terutama pada atribut dokter memberikan kesempatan bertanya pada pasien (RS2) yaitu sebanyak 81 responden dengan bobot 336.

\section{d) Dimensi Assurance}

Dimensi assurance diwakilkan oleh 3 atribut, yaitu keramahan dan kesantunan petugas pendaftaran dan kasir (A1), terciptanya suasana kekeluargaan antara dokter dan pasien (A2), terciptanya suasana kekluargaan antara perawat dan pasien (A3). Distribusi penilaian tingkat harapan dan kenyataan responden terhadap pelayanan berdasarkan dimensi assurance dapat dilihat pada Tabel 8 dibawah ini :

Tabel 8 Distribusi Penilaian Responden terhadap Tingkat Harapan Pelayanan berdasarkan Dimensi assurance

\begin{tabular}{lccccc}
\hline Atribut & \multicolumn{3}{c}{ Jawaban } & Bobot \\
\cline { 2 - 5 } & STPTP & P & SP & \\
\hline A1 & 0 & 0 & 65 & 45 & 375 \\
A2 & 1 & 1 & 71 & 37 & 363 \\
A3 & 1 & 1 & 70 & 38 & 377 \\
\hline
\end{tabular}

Dari Tabel 8 diketahui bahwa distribusi jawaban responden mengenai tingkat harapan terhadap pelayanan berdasarkan dimensi assurance adalah sebagian besar responden menyatakan penting terutama pada atribut terciptanya suasana kekeluargaan antara 
dokter dan pasien yaitu sebanyak 71 responden dengan bobot 363

Tabel 9 Distribusi Penilaian Responden terhadap Tingkat Kenyataan Pelayanan berdasarkan Dimensi assurance

\begin{tabular}{lllll}
\hline Atribut & \multicolumn{3}{c}{ Jawaban } & Bobot \\
\cline { 2 - 5 } & STP & TP & P & SP \\
\hline A1 & 1 & 33 & 57 & 19314 \\
A2 & 0 & 10 & 75 & 25345 \\
A3 & 0 & 10 & 77 & 23333 \\
\hline
\end{tabular}

Dari Tabel 9 diketahui bahwa penilaian responden mengenai tingkat kenyataan atau kepuasan terhadap pelayanan berdasarkan dimensi assurance adalah sebagian besar responden menyatakan puas terutama pada atribut terciptanya suasana kekeluargaan antara dokter dan pasien yaitu sebanyak 75 responden dengan bobot 345 .

\section{e) Dimensi Empathy}

Dimensi empathy diwakilkan oleh 4 atribut, yaitu dokter memberikan waktu pelayanan yang cukup pada pasien (E1), perawat memperhatikan sungguh - sungguh kepada pasien (E2), pemberi pelayanan terhadap pasien tanpa pilih - pilih (E3), dan adanya kotak saran untuk kritik dan saran (E4). Distribusi penilaian tingkat harapan dan kenyataan responden terhadap pelayanan berdasarkan dimensi empathy dapat dilihat pada Tabel 10 dibawah ini :
Tabel 10 Distribusi Jawaban Responden terhadap Tingkat Harapan Pelayanan berdasarkan Dimensi empathy

\begin{tabular}{llllll}
\hline Atribut & \multicolumn{3}{c}{ Jawaban } & \multicolumn{2}{c}{ Bobot } \\
\cline { 2 - 5 } & STP & TP & P & \multicolumn{2}{c}{ SP } \\
\hline E1 & 0 & 0 & 65 & 45 & $375^{*}$ \\
E2 & 0 & 0 & 58 & 52 & 382 \\
E3 & 0 & 0 & 54 & 56 & 386 \\
E4 & 0 & 5 & 73 & 32 & 357 \\
\hline
\end{tabular}

Dari Tabel 10 diketahui bahwa penilaian responden mengenai tingkat harapan terhadap pelayanan berdasarkan dimensi empathy adalah sebagian besar responden menyatakan penting terutama pada atribut adanya kotak saran yaitu sebanyak 73 responden dengan bobot 364 .

Tabel 11 Distribusi Jawaban Responden terhadap Tingkat Kenyataan Pelayanan berdasarkan Dimensi empathy

\begin{tabular}{|c|c|c|c|}
\hline Atribut & \multicolumn{2}{|c|}{ Jawaban } & \multirow{2}{*}{ Bobot } \\
\hline & $\overline{\text { STP TI }}$ & $\mathbf{P}$ & \\
\hline$\overline{\mathrm{E} 1}$ & $\begin{array}{ll}2 & 16\end{array}$ & 76 & 16326 \\
\hline E2 & 12 & 81 & 17335 \\
\hline E3 & 2 & 80 & 19336 \\
\hline E4 & 8 & 87 & 13331 \\
\hline
\end{tabular}
responden mengenai tingkat kenyataan atau kepuasan terhadap pelayanan berdasarkan dimensi empathy adalah sebagian besar responden menyatakan puas terutama pada atribut adanya kotak saran yaitu sebanyak 87 responden dengan bobot 331 . 


\section{Diskusi}

a. Gambaran Kepuasan Pasien Rawat Jalan Berdasarkan Dimensi Tangible

Dimensi bukti fisik (Tangible) dalam hal ini, pengguna jasa menggunakan inderanya (mata, telinga dan rasa) untuk menilai kualitas jasa pelayanan kesehatan yang diterima, misalnya ruang penerimaan pasien yang bersih dan nyaman dilengkapi dengan kursi, lantai berkeramik, TV, peralatan kantor yang lengkap, seragam staf yang rapi, menarik dan bersih.

Tangible yang baik akan mempengaruhi persepsi pelanggan. Pada saat bersamaan dimensi tangible ini juga merupakan salah satu sumber yang memperngaruhi kepuasan pelanggan. Karena tangible yang baik, maka harapan pelanggan terhadap pelayanan menjadi lebih tinggi. Oleh karena itu, penting bagi perusahaan untuk mengetahui seberapa jauh dimensi tangible yang paling tepat.

Dimensi tangible diwakilkan oleh lima atribut yaitu tenaga medis dan karyawan rumah sakit berpenampilan rapi dan bersih (T1), kebersihan dan kenyamanan ruang tunggu (T2), kebersihan poli rawat jalan (T3), kebersihan kamar mandi pasien (T4), dan adanya media elektronik tv diruang tunggu (T5). Deskripsi masing-masing atribut berdasarkan distribusi penilaian tingkat kepentingan (harapan) dan tingkat pelaksanaan ( kenyataan) adalah sebagai berikut:

1) Tenaga Medis dan karyawan rumah sakit berpenampilan rapi dan bersih
Penampilan seorang tenaga medis atau karyawan pada saat menemui pasien menjadi sangat penting karena pasien akan merasa nyaman dalam menerima pelayanan jika tenaga medis atau karyawan rumah sakit berpenampilan rapi dan bersih. Untuk itu atribut ini termasuk pada bagian yang penting bagi pasien. Dari hasil penelitian dalam lapiran 4 diketahui bahwa mayoritas responden merasa atribut ini penting yaitu sebanyak 71 orang (64,5\%), sejalan dengan tingkat penilaian pelaksanaannya mayoritas responden merasa atribut ini puas yaitu sebanyak 84 orang $(76,4 \%)$. Hasil penelitian ini sejalan dengan penelitian lain mengenai analisis kepuasan pasien di rumah sakit Husada Jakarta Kurniana, dalam penelitiannya mendapatkan hasil sebanyak 68 orang menganggap atribut ini penting dan 61 orang pasien menyatakan rasa puasnya mengenai atribut ini.

2) Kebersihan dan kenyamanan ruang tunggu

Kebersihan dan kenyamanan merupakan hal yang penting bagi pasien agar memiliki loyalitas yang tinggi pada rumah sakit, sehingga pihak rumah sakit harus terus menjaga kebersihan. Dari hasil penelitian dalam lapiran 4 diketahui bahwa mayoritas responden merasa atribut ini penting yaitu sebanyak 59 orang $(53,6)$ dan untuk penilaian responden terhadap tingkat pelaksanaannya mayoritas responden merasa atribut ini puas yaitu sebanyak 78 orang $(70,9 \%)$. Hasil penelitian ini tidak sejalan dengan penelitian 
Hamid, mengenai tingkat kepuasan pasien rawat jalan di RSUD dr. H. Marzuki Mahdi Bogor diperoleh hasil penelitian mayoritas responden (53\%) menganggap atribut ini penting dan untuk tingkat penilaian pelaksanaannya (55\%) responden menganggap atribut tersebut tidak puas.

Adanya perbedaan hasil dikarenakan oleh banyak faktor diantaranya perbedaan penggunaan pengukuran tingkat kepuasan, aspek operasional dalam pengumpulan data, pemahaman terhadap pelayanan yang berbeda - beda dan kepuasan merupakan sesuatu yang bersifat subjektif.

\section{3) Kebersihan poli rawat jalan}

Kebersihan ruangan poli rawat jalan yang terjaga akan membuat pasien merasa nyaman untuk berobat di rumah sakit. Dari hasil penelitian diketahui bahwa mayoritas responden menganggap atribut ini penting yaitu sebanyak 65 orang $(59,1 \%)$ dan untuk penilaian responden terhadap tingkat pelaksanaannya adalah mayoritas responden merasa puas yaitu sebanyak 75 orang $(68,2 \%)$. Hasil penelitian ini sejalan dengan penelitian Hamid, mengenai tingkat kepuasan pasien rawat jalan di RSUD dr. h. Marzuki Mahdi Bogor diperoleh hasil penelitian mayoritas responden (56\%) menganggap atribut ini penting dan untuk tingkat penilaian pelaksanaannya $(41 \%)$ responden menganggap atribut tersebut puas.

4) Kebersihan kamar mandi pasien
Dalam memberikan pelayanan kepada pasien tentu dibutuhkan adanya berbagai sarana yang berguna untuk mendukung memenuhi kebutuhan pasien sebagai pengguna pelayanan kesehatan untuk itu salah satunya adalah adanya kamar mandi pasien, sehingga kebersihan kamar mandi perlu dapat perhatian bagi rumah sakit demi kebutuhan pasien sebagai pengguna pelayanan.

Berdasarkan hasil penelitian diketahui bahwa mayoritas responden menganggap atribut ini penting yaitu sebanyak 59 orang $(53,6 \%)$ dan untuk penilaian responden terhadap tingkat pelaksanaannya mayoritas responden merasa atribut ini tidak puas yaitu sebanyak 54 orang $(49,1 \%)$. Hal ini menunjukan bahwa atribut ini belum memuaskan seperti harapan pasien. Menurut Silalahi (1989, dalam Muharmawati, 2004) menyatakan bahwa ruangan-ruangan kritikal seperti kamar mandi, bangsal, kamar bedah, ruang perawat harus rapi, teratur dan bersih serta air yang digunakan harus bersih dan cukup.

5) Adanya media elektronik tv diruang tunggu

Adanya tv diruang tunggu merupakan salah satu sarana hiburan agar keluarga pasien atau pasien tidak mengalami kejenuhan dalam menunggu dalam antrian pemeriksaan.

Dari hasil penelitian diketahui bahwa mayoritas responden menganggap atribut ini penting yaitu sebanyak 77 orang $(70,0 \%)$ dan untuk penilaian responden terhadap tingkat 
pelaksanaannya mayoritas responden merasa atribut ini puas yaitu sebanyak 78 orang (70,9\%). Hasil penelitian ini sejalan dengan penelitian Hamid, mengenai tingkat kepuasan pasien rawat jalan di RSUD dr. H. Marzuki Mahdi Bogor diperoleh hasil penelitian mayoritas responden (41\%) menganggap atribut ini penting dan untuk tingkat penilaian pelaksanaannya (41\%) responden menganggap atribut tersebut puas.

\section{b. Gambaran Kepuasan Pasien Rawat} Jalan Berdasarkan Dimensi Reliability

Kepuasan pelanggan terhadap pelayanan juga ditentukan oleh dimensi reliability, yaitu dimensi yang mengukur kehandalan dari perusahaan dalam memberikan pelayanan kepada pelanggannya. Dibandingkan dengan 4 dimensi kualitas pelayanan lainnya, yaitu responsiveness, assurance, empathy, dan tangible, dimensi ini sering dipersepsi paling penting bagi pelanggan dari berbagai industri jasa.

Dimensi reliability diwakilkan oleh 5 atribut, yaitu kedisiplinan waktu pelayanan (RL1), prosedur penerimaan pasien dilayani secara cepat dan tidak berbelit-belit (RL2), kecepatan bagian pendaftaran dan kasir dalam pelayanan (RL3), ketepatan waktu dokter dalam memulai memberikan pelayanan (RL4), dan ketepatan waktu perawat dalam memulai memberikan pelayanan (RL5). Deskripsi masing-masing atribut berdasarkan distribusi penilaian tingkat kepentingan (harapan) dan tingkat pelaksanan (kenyatan) adalah sebagai berikut :

1) Kedisiplinan waktu pelayanan

Dari hasil penelitian diketahui bahwa hasil penilaian responden merasa atribut ini sangat penting dan penting yaitu sebanyak 55 orang $(50,0 \%)$

dan penting 55 orang (50\%) sejalan dengan tingkat pelaksanaannnya mayoritas reponden merasa atribut ini puas yaitu 71 orang $(64,5 \%)$. Hasil penlitian ini menunjukan bahwa penilaian responden menganggap atribut ini sangat penting dan penting oleh karena itu diharapkan untuk pelaksanaannya lebih diupayakan sehingga dapat memenuhi apa yang diharapkan pasien. Sebagaimana menurut Goetsch \& Davis, Kedisiplinan waktu pelayanan yang dilaksanakan dengan tepat merupakan suatu wujud kedisiplinan petugas kesehatan dalam melaksanakan tugasnya dan komitmennya terhadap ketetapan suatu institusi untuk kelancaran pelayanan dan peningkatan mutu pelayanan.

Berdasarkan saran dari salah satu respoden bahwa "jadwal praktek dokter masih ada tapi tidak mau melayani”. Hal ini menunjukan kedisiplinan waktu pelayanan masih kurang dalam pelaksanaannya

2) Prosedur penerimaan pasien dilayani secara cepat dan tidak berbelit-belit

Dalam memberikan pelayanan yang efektif, salah satu faktor yang harus diperhatikan oleh pemberi jasa adalah melaksanakan pelayanan yang tidak berbelitbelit. Dari hasil penelitian diketahui bahwa 
hasil penilaian responden menganggap atribut ini sangat penting yaitu sebanyak 60 orang $(54,5 \%)$ dan untuk tingkat pelaksanaannnya mayoritas reponden merasa atribut ini puas yaitu 64 orang $(58,2 \%)$. Hasil penlitian ini menunjukan bahwa atribut ini sudah baik. Sebagaimana menurut Azwar, Rumah sakit yang memberikan pelayanan kesehatan kepada masyarakat dalam pelaksanaannya harus pula memperhatikan prosedur pelayanan agar tidak berbelit-belit dan menambah masalah yang dihadapi oleh pasien akan tetapi harus memberikan kemudahan dan kecepatan pelayanan sehingga kebutuhan pasien akan pelayanan segera terpenuhi dan memberikan kepuasan.

3) Kecepatan bagian pendaftaran dan kasir dalam pelayanan

Pelayanan dengan kecepatan waktu yang sesuai dengan standar pada pelaksanaannya sangatlah diperlukan. Pelayanan yang cepat mencerminkan kepedulian pemberi pelayanan terhadap efektifitas dan efisiensi waktu bagi pemberi pelayanan dan penerima pelayanan (pasien). Dari hasil penelitian diketahui mayoritas responden menganggap atribut ini penting yaitu sebanyak 57 orang $(51,8)$ dan untuk tingkat pelaksanaannya yaitu mayoritas responden menganggap atribut ini puas yaitu sebanyak 68 orang $(61,8 \%)$. Hasil penelitian ini menunjukan bahwa atribut ini sudah baik sebagaimana Menurut Azwar, bahwa semakin efisien suatu pelayanan kesehatan, semakin tinggi pula mutu pelayanan kesehatan.

4) Ketepatan waktu dokter dalam memulai memberikan pelayanan

Dari hasil penelitian dalam lapiran 4 diketahui bahwa mayoritas responden merasa atribut ini sangat penting yaitu sebanyak 55 orang $(55,0 \%)$, dan untuk tingkat penilaian pelaksanaannya mayoritas responden merasa atribut ini puas yaitu sebanyak 62 orang $(56,4 \%)$. Hasil penelitian ini sejalan dengan penelitian lain mengenai analisis kepuasan pasien di rumah sakit Husada Jakarta Kurniana, dalam penelitiannya mendapatkan hasil sebanyak 51 orang menganggap atribut ini sangat penting dan 46 orang pasien menyatakan rasa puasnya mengenai atribut ini.

5) Ketepatan waktu perawat dalam memulai memberikan pelayanan

Dari hasil penelitian diketahui mayoritas responden menganggap atribut ini sangat penting yaitu sebanyak 57 orang $(51,8)$ dan untuk tingkat pelaksanaannya yaitu mayoritas responden menganggap atribut ini puas yaitu sebanyak 74 orang $(67,3 \%)$. Hasil penelitian ini menunjukan bahwa atribut ini sudah baik sebagaimana Menurut Goetsch \& Davis, menyatakan tentang ketepatan waktu merupakan bagian integral dari sistem mutu total. Oleh karena itu ketepatan waktu dalam memberikan pelayanan sangat diperlukan karena ketepatan waktu merupakan bagian dari mutu pelayanan. 
c. Gambaran Kepuasan Pasien Rawat

Jalan Berdasarkan

Dimensi

\section{Responsiveness}

Responsiveness adalah dimensi kualitas pelayanan yang paling dinamis. Harapan pelanggan terhadap kecepatan pelayanan hampir dapat dipastikan akan berubah dengan kecenderungan naik dari waktu ke waktu. Pelayanan yang tanggap, juga sangat dipengaruhi oleh sikap front line staf (petugas yang berhadapan langsung dengan pelanggan). Salah satunya adalah kesigapan dan ketulusan dalam menjawab pertanyaan atau permintaan pelanggan.

Dimensi responsiveness diwakilkan oleh 3 atribut, yaitu cepat tanggap dokter dan perawat dalam mengatasi keluhan pasien (RS1), dokter memberikan kesempatan bertanya kepada pasien (RS2), cepat tanggap petugas pendaftaran dan kasir dalam membantu pasien (RS3). Deskripsi masing-masing atribut berdasarkan distribusi penilaian tingkat kepentingan (harapan) dan tingkat pelaksanan (kenyatan) adalah sebagai berikut:

1) Cepat tanggap dokter dan perawat dalam mengatasi keluhan pasien

Respon yang baik dalam menyikapi keluhan yang disampaikan merupakan suatu hal yang sangat diharapkan pasien, sebagai wujud dari berperan sertanya petugas kesehatan untuk cepat tanggap dalam menyikapi masalah yang dihadapi pasien. Menurut Goestch \& Davis, Dari hasil penelitian dalam lapiran 4 diketahui bahwa mayoritas responden merasa atribut ini sangat penting yaitu sebanyak 61 orang $(55,5 \%)$, dan untuk tingkat penilaian pelaksanaannya mayoritas responden merasa atribut ini puas yaitu sebanyak 72 orang $(65,5 \%){ }^{11}$ Hasil penelitian ini sejalan dengan penelitian lain mengenai analisis kepuasan pasien di rumah sakit Husada Jakarta Kurniana, dalam penelitiannya mendapatkan hasil sebanyak 51 orang menganggap atribut ini sangat penting dan 46 orang pasien menyatakan rasa puasnya mengenai atribut ini.

2) Dokter memberikan kesempatan bertanya kepada pasien

Dokter yang senantiasa lebih intensif dalam melayani pasien dengan memberikan kesempatan bertanya kepada pasien untuk meningkatkan kepuasan pasien.

Dari hasil penelitian diketahui bahwa mayoritas responden menganggap atribut ini penting yaitu sebanyak 73 orang $(66,4 \%)$ dan untuk tingkat pelaksanaannya mayoritas responden menganggap atribut ini puas yaitu 81 orang $(73,6 \%)$. Hal ini menunjukan komunikasi antara dokter dan pasien sudah baik. Menurut Ley (1992, dalam Suparman, 2002), menyatakan fakrot terpenting yang memberikan kepuasan terhadap pelayanan kesehatan adalah komunikasi antara tenaga kesehatan dan pasien. ${ }^{12}$ Menurut Wolf (1984, dalam Suparman, 2002) menyatakan bahwa pasien mengharapkan mendapat penjelasan tentang pemeliharaan kesehatan mereka dan menginginkan pertanyaan-pertanyaan mereka 
dijawab.

3) Cepat tanggap petugas pendaftaran dan kasir dalam membantu pasien

Kebutuhan pasien terhadap pelayanan administrasi berbagai macam jenisnya. Atribut ini sangat penting karena biasanya pasien mengalami kesulitan untuk melakukan pendaftaran atau pembayaran. Hal ini tentunya membutuhkan kesigapan petugas untuk membantu pasien. Bila hal tersebut diabaikan maka akan timbul kekecewaan terhadap pasien yang pada akhirnya dikhawatirkan akan berpaling ke rumah sakit yang lain

Dari hasil penelitian diketahui bahwa mayoritas responden menganggap atribut ini penting yaitu sebanyak 63 orang $(57,3 \%)$ dan untuk tingkat pelaksanaannya mayoritas responden menganggap atribut ini puas yaitu sebanyak 72 orang $(65,5 \%)$. Hasil penelitian ini sejalan dengan penelitian Hamid, mengenai tingkat kepuasan pasien rawat jalan di RSUD dr. h. Marzuki Mahdi Bogor diperoleh hasil penelitian mayoritas responden (56\%) menganggap atribut ini penting dan untuk tingkat penilaian pelaksanaannya (57\%) responden menganggap atribut tersebut puas.

\section{d. Gambaran Kepuasan Pasien Rawat} Jalan Berdasarkan Dimensi Assurance

Dimensi assurance merupakan dimensi kualitas yang berhubungan dengan dengan kemampuan perusahaan dan perilaku front line staf dalam menanamkan rasa percaya dan keyakinan kepada para pelanggannya.
Berdasarkan riset yang dilakukan, ada empat aspek dari dimensi ini,yaitu keramahan, kompetensi, kredibilitas dan keamanan. ${ }^{6}$

Dimensi assurance diwakilkan oleh 3 atribut, yaitu keramahan dan kesantunan petugas pendaftaran dan kasir (A1), terciptanya suasana kekeluargaan antara dokter dan pasien (A2), terciptanya suasana kekluargaan antara perawat dan pasien (A3). Deskripsi masing-masing atribut berdasarkan dastribusi penilaian tingkat kepentingan (harapan) dan tingkat pelaksanaan (kenyataan) adalah sebagai berikut :

1) Keramahan dan kesantunan petugas pendaftaran dan kasir.

Keramahan pelayanan (serviceability) yang didalamnya terdapat keramahan dari pemberi produk atau jasa merupakan salah satu karakteristik yang digunakan untuk menganalisa suatu kualitas produk atau jasa. ${ }^{11}$

Dari hasil penelitian diketahui bahwa mayoritas responden menganggap atribut ini penting yaitu sebanyak 65 orang $(59,1 \%)$ dan untuk tingkat pelaksanaannya mayoritas responden menganggap atribut ini puas yaitu sebanyak 57 orang $(51,8 \%)$. Hasil penelitian ini sejalan dengan penelitian Hamid, mengenai tingkat kepuasan pasien rawat jalan di RSUD Dr. H. Marzuki Mahdi Bogor diperoleh hasil penelitian mayoritas responden (57\%) menganggap atribut ini penting dan untuk tingkat penilaian pelaksanaannya $(55 \%)$ responden menganggap atribut tersebut puas.

2) Terciptanya suasana kekeluargaan antara 
dokter dan pasien

Hubungan antara dokter dan pasien harus dijalin sedemikian rupa sehingga terjalin kedekatan antara dokter dan pasien, oleh karena atribut ini sangat penting untuk meningkatkan loyalitas pasien karena pasien lebih merasa nyaman dan pengobatan dapat lebih optimal.

Dari hasil penelitian diketahui bahwa mayoritas responden menganggap atribut ini penting yaitu sebanyak 71 orang $(64,5 \%)$ dan untuk tingkat pelaksanaannya mayoritas responden menganggap atribut ini puas yaitu sebanyak 81 orang $(73,6 \%)$. Hasil penelitian ini sejalan dengan penelitian Hamid, mengenai tingkat kepuasan pasien rawat jalan di RSUD dr. H. Marzuki Mahdi Bogor diperoleh hasil penelitian mayoritas responden (56\%) menganggap atribut ini penting dan untuk tingkat penilaian pelaksanaannya (52\%) responden menganggap atribut tersebut puas.

3) Terciptanya suasana kekeluargaan antara perawat dan pasien

Hubungan yang baik antara perawat dan pasien dapat menciptakan suasana yang dapat membuat pasien merasa nyaman dalam menerima pelayanan karena hal ini dapat membantu dalam memenuhi kebutuhan pelayanan

Dari hasil penelitian diketahui bahwa mayoritas responden menganggap atribut ini penting yaitu sebanyak 70 orang $(63,6 \%)$ dan untuk tingkat pelaksanaannya mayoritas responden menganggap atribut ini puas yaitu sebanyak 54 orang $(49,1 \%)$. Hasil penelitian ini sejalan dengan penelitian Hamid, mengenai tingkat kepuasan pasien rawat jalan di RSUD dr. H. Marzuki Mahdi Bogor diperoleh hasil penelitian mayoritas responden (59\%) menganggap atribut ini penting dan untuk tingkat penilaian pelaksanaannya (52\%) responden menganggap atribut tersebut puas.

\section{e. Gambaran Kepuasan Pasien Rawat} Jalan Berdasarkan Dimensi Empathy

Dimensi empathy adalah dimensi kelima dari dari kualitas pelayanan. Secara umum, dimensi ini memang dipersepsi kurang penting disbandingkan dengan dimensi reliability dan responsiveness dimata kebanyakan pelanggan dimensi empathy adalah dimensi yang memberikan peluang yang bersifat "surprise" sesuatu yang kurang diharapkan pelanggan tetapi dilakukan untuk menyenangkan pelnggan. Pelayanan yang berempati, akan mudah diciptakan, jika setiap karyawan perusahaan mengerti kebutuhan pelanggan.

Dimensi empathy diwakilkan oleh 4 atribut, yaitu dokter memberikan waktu pelayanan yang cukup pada pasien (E1), perawat memperhatikan sungguh-sungguh pada pasien (E2), pemberi pelayanan terhadap pasien tanpa pilih-pilih (E3), dan adanya kotak saran (E4). Deskripsi masing-masing atribut berdasarkan dastribusi penilaian tingkat kepentingan (harapan) dan tingkat pelaksanaan (kenyataan) adalah sebagai berikut :

1) Dokter memberikan waktu yang cukup 
pada pasien

Sebagian dokter merasa tidak mempunyai waktu yang cukup untuk berbincang-bincang dengan pasiennya, sehingga hanya bertanya seperlunya. Akibatnya, dokter bisa saja tidak mendapatkan keterangan yang cukup untuk menegakkan diagnosis dan menentukan perencanaan dan tindakan lebih lanjut.

Berdasarkan hasil penelitian diketahui bahwa mayoritas responden merasa atribut ini sangat penting yaitu sebanyak 65 orang $(59,1 \%)$, dan untuk tingkat penilaian pelaksanaannya mayoritas responden merasa atribut ini puas yaitu sebanyak 76 orang $(69,1 \%)$. Hasil penelitian ini sejalan dengan penelitian lain mengenai analisis kepuasan pasien di rumah sakit Husada Jakarta Kurniana, dalam penelitiannya mendapatkan hasil sebanyak 51 orang menganggap atribut ini sangat penting dan 43 orang pasien menyatakan rasa puasnya mengenai atribut ini.

2) Perawat memperhatikan sungguh - sungguh kepada pasien

Dari hasil penelitian diketahui bahwa mayoritas responden merasa atribut ini sangat penting yaitu sebanyak 58 orang $(52,7 \%)$, dan untuk tingkat penilaian pelaksanaannya mayoritas responden merasa atribut ini puas yaitu sebanyak 81 orang $(73,6 \%)$. Hasil penelitian ini sejalan dengan penelitian lain mengenai analisis kepuasan pasien di rumah sakit Husada Jakarta Kurniana, dalam penelitiannya mendapatkan hasil sebanyak 61 orang menganggap atribut ini sangat penting dan 43 orang pasien menyatakan rasa puasnya mengenai atribut ini.

3) Pemberi pelayanan terhadap pasien tanpa pilih - pilih

Secara filosofi, Lumenta mengatakan bahwa setiap manusia memiliki hak dan martabat yang sama, berawal dari pemikiran ini jika dikaitkan dengan hubungan antara pasien dengan petugas kesehatan, kedua belah pihak harus terbuka dan membina hubungan yang serasi.

Dari hasil penelitian diketahui bahwa mayoritas responden menganggap atribut ini sangat penting yaitu sebanyak 56 orang $(50,9 \%)$ dan untuk tingkat pelaksanaannya mayoritas responden menganggap atribut ini puas yaitu sebanyak 80 orang (72,7\%). Hasil penelitian ini sejalan dengan penelitian Hamid, mengenai tingkat kepuasan pasien rawat jalan di RSUD dr. H. Marzuki Mahdi Bogor diperoleh hasil penelitian mayoritas responden (59\%) menganggap atribut ini penting dan untuk tingkat penilaian pelaksanaannya (52\%) responden menganggap atribut tersebut puas.

4) Adanya kotak saran

Adanya kotak saran merupakan bentuk perhatian pihak rumah sakit Karena menyediakan sarana untuk pasien menyampaikan keriktikan atau keluahan yang mereka rasakan terhadap pelayanan yang telah diterimanya dengan begitu hal ini bisa sebagai sarana bahan masukan dan kritikan untuk perbaikan rumah sakit untuk kedepannya 
dalam memenuhi kebutuhan pelayanan.

Dari hasil penelitian diketahui bahwa mayoritas responden menganggap atribut ini penting yaitu sebanyak 73 orang $(66,4 \%)$ dan untuk tingkat pelaksanaannya mayoritas responden menganggap atribut ini puas yaitu sebanyak 87 orang $(79,1 \%)$. Hasil penelitian ini tidak sejalan dengan penelitian Hamid, mengenai tingkat kepuasan pasien rawat jalan di RSUD dr. H. Marzuki Mahdi Bogor diperoleh hasil penelitian mayoritas responden (58\%) menganggap atribut ini penting dan untuk tingkat penilaian pelaksanaannya (38\%) responden menganggap atribut tersebut netral. ${ }^{9}$

Adanya perbedaan hasil dikarenakan oleh banyak faktor diantaranya perbedaan penggunaan pengukuran tingkat kepuasan, aspek operasional dalam pengumpulan data, pemahaman terhadap pelayanan yang berbedabeda dan kepuasan merupakan sesuatu yang bersifat subjektif.

\section{Simpulan}

Berdasarkan uji IPA hasil pengukuran atribut-atribut pelayanan di RSIJ Sukapura berdasarkan tingkat kepentingan (harapan) dan tingkat pelaksanaannya atau kepuasan (kenyataan) sebagai berikut :

a. Atribut-atribut mutu pelayanan RSIJ Sukapura yang berada pada kuadran A (prioritas utama) adalah : 1) Kebersihan kamar mandi pasien, 2) Kebersihan poli rawat jalan, 3) Ketepatan waktu dokter dalam memulai memberikan pelayanan, 4)
Kedisiplinan waktu pelayanan, dan 5) Keramahan dan Kesantunan petugas pendaftaran dan Kasir.

b. Atribut-atribut mutu pelayanan RSIJ Sukapura yang berada pada kuadran B (pertahankan prestasi) adalah : 1) Prosedur penerimaan pasien dilayani secara cepat dan tidak terbelit-belit, 2) Kecepatan bagian pendaftaran dan kasir dalam pelayanan, 3) Ketepatan waktu perawat dalam memberikan pelayanan, 4) Cepat tanggap dokter dan perawat dalam mengatasi keluhan pasien, 5) Cepat dan tanggap bagian pendaftaran dan kasir dalam membantu pasien, 6) Perawat memperhatikan sungguh-sungguh kepada pasien, dan 7) Pemberian pelayanan terhadap pasien tanpa pilih-pilih.।

c. Atribut-atribut mutu pelayanan RSIJ Sukapura yang berada pada kuadran C (prioritas rendah) adalah : 1) Terciptanya suasana kekeluargaan antara perawat dengan pasien, dan 2) Adanya TV diruang tunggu.

d. Atribut yang berada pada kuadran D (berlebihan) adalah: 1) Kebersihan dan kenyamanan ruang tunggu, 2) Dokter memberikan waktu pelayanan yang cukup pada pasien, 3) Terciptanya suasana kekeluargaan antara dokter dan Pasien, 4) Dokter memberikan kesempatan bertanya kepada pasien, 5) Adanya kotak saran untuk kritik dan keluhan, dan 6) Tenaga medis dan karyawan rumah sakit 
berpenampilan rapi dan bersih.

\section{Daftar Pustaka}

1. Departemen Kesehatan. Rencana Strategis Kementerian Kesehatan Tahun 2015-2019. Jakarta. $2015 . \quad$ Online: www.depkes.go.id.,/Renstra-2015.pdf diakses pada 19 Agustus 2015.

2. Supranto. Pengukuran Tingkat Kepuasan Pelanggan. Jakarta: Rineka Cipta. 2011.

3. Supriyanto, Yuda dan Soesanto, $\mathbf{H}$. Analisis Pengaruh Kualitas Pelayanan, Harga, dan Fasilitas Terhadap Kepuasan Pasien Rawat Jalan di Rumah Sakit Kariadi Semarang. Diponegoro Journal of Management 2012 Volume 1, Nomor 1 : $472-480$

4. Azwar, A. Mejaga Mutu Pelayanan Kesehatan. Jakarta. Pustaka Sinar Harapan. 1996.

5. Wijono, D. Manajemen mutu pelayanan kesehatan. Surabaya ; Airlangga University Press, 1999.

6. Muninjaya, G. Manajemen Mutu Pelayanan Kesehatan. Jakarta ; Buku Kedokteran EGC, 2011.

7. Irawan, H. 10 Prinsip Kepuasan Pelanggan. Jakarta ; PT Elex Media Komputerindo, 2010.

8. Kurniana. Analisis Kepuasan Pasien Terhadap Pelayanan Rawat Inap di Rumah Sakit Husada Jakarta Tahun 2008. Tesis Magister Ilmu Administrasi Kekhususan: Administrasi dan Kebijakan Bisnis.
Depok: Universitas Indonesia, 2008.

9. Hamid. Analisis Tingkat Kepuasan Pasien Rawat Jalan di Rumah Sakit DR. H. Marzoeki Mahdi Bogor. Skripsi IPB Bogor, $2010 . \quad$ Online: http://repository.ipb.ac.id/bitstream/han dle/123456789/62572/H10ham.pdf?seq uence $=1$ diakses 11 Mei 2015

10. Muharmawati, R. Gambaran Persepsi Pasien/Keluarga Pasien Rawat Inap Kelas III Terhadap Pelayanan Kesehatan Di Rumah Sakit Angkatan Lut Marinir Cilandak Tahun 2004, Skripsi, FKM UI, 2004.

11. Goetsch, David L Davis. Total Quality Management. Jakarta: Prenhallindo (terjemahan), 1997.

12. Suparman, A. Gambaran Kepuasan Pasien Terhadap Pelayanan Kesehatan Rawat Jalan Di Puskesmas Mandalika Kabupaten Ciamis Provinsi Jawa Barat Tahun 2002, Skripsi FKM UI,2002.

13. Konsil Kedokteran Indonesia. Komunikasi Efektif Dokter-Pasien. 2006. (Online), s \&did=MjUuaG90bGluaw diakses 21 September 2015

14. Lumenta, B. Pasien, Citra, Peran, dan Prilaku Tinjauan Fenomena Sosial, Cetakan 1. Kanisius, Yogyakarta, 1989. 